\title{
Studies on Productive Performance and Biometry in Traditionally Reared Indigenous Goats of Andhra Pradesh
}

\author{
Lakshmi Parvathi, A. ${ }^{1}$, Punya Kumari, B. ${ }^{1 "}$, Sakuntala Devi, K. ${ }^{2}$, Ravindra Reddy, Y. ${ }^{3}$ and Vinod, U. ${ }^{1}$ \\ ${ }^{1}$ Department of Animal Genetics and Breeding, College of Veterinary Science, SVVU-Tirupati-INDIA \\ ${ }^{2}$ Department of Animal Genetics and Breeding, College of Veterinary Science, SVVU-Proddatur-INDIA \\ ${ }^{3}$ Department of Livestock Production and Management, College of Veterinary Science, SVVU-Tirupati-INDIA \\ "Corresponding author: B.Punya Kumari; E-mail: punya67@yahoo.co.in
}

Received: 21 Oct., 2020

Revised: 02 Nov., 2020

Accepted: 18 Nov., 2020

\begin{abstract}
Data collected on body weights and biometrical measurements i.e., height at withers, chest girth, body length, hip width, paunch girth, face length, ear length and tail length of 1421 goats at milk teeth, 2, 4, 6 and 8-teeth of age reared under field conditions in Rayalaseema region (Chittoor, YSR Kadapa, Anantapur and Kurnool) of Andhra Pradesh were subjected to least squares analysis to study the effect of district and sex. The least squares analysis of variance revealed significant effects of district and sex on body weights and measurements at one or the other ages studied. The overall least squares mean body weights $(\mathrm{kg})$ at milk teeth, 2, 4, 6 and 8-teeth ages were $13.97 \pm \pm 0.16,20.57 \pm 0.38,26.56 \pm 0.68,30.66 \pm 0.62$ and $34.64 \pm 0.85$, respectively. The overall least squares means for height at withers, chest girth, body length, hip width, paunch girth, face length, ear length and tail length at milk teeth age were $66.60 \pm 0.29,61.08 \pm 0.25,53.24 \pm 0.25,13.02 \pm 0.08,61.05 \pm 0.27,16.65 \pm 0.10,14.66$ \pm 0.08 and $14.51 \pm 0.09 \mathrm{~cm}$, respectively and the corresponding means at 8 teeth were $84.07 \pm 0.72,82.83 \pm 0.69,69.66 \pm 0.99$, $18.05 \pm 0.56,83.50 \pm 0.95,20.78 \pm 0.24,16.39 \pm 0.30$ and $16.56 \pm 0.32 \mathrm{~cm}$. The least squares mean were higher in males than in females and increased as age advances.
\end{abstract}

\section{HIGHLIGHTS}

(0 The body weights and biometrical measurements linearly increased with age.

(0 All the biometrical parameters revealed increase in trend with the advancement of the age.

Keywords: Biometrical measurements, Body weight and Indigenous goats

Goats play a substantial role in food production systems and are often recognized as a multipurpose animal capable of enhancing rural economy. Low input, high prolificacy, easy marketing and consumer acceptance for goat products gained much popularity to goat breeding. In India, more than 70 per cent of marginal farmers prefer to rear small ruminants rather than cows or buffaloes. A large number of rural households' rear goats with the flock size varying from 3 to 4 breeding does on an average. These flocks represent more than $90 \%$ of the goat population. India is a rich repository of goat germplasm with 34 defined goat breeds with 148.88 million populations (Livestock Census, 2019) and constitutes $24.40 \%$ of total livestock of the country. Andhra Pradesh possesses about 64.27 lakhs goats which constitutes 2.316 percent of the total country's goat population. Breed characterization has traditionally been recognized as the first approach for the sustainable use of animal genetic resources. Although, goats are extensively reared by the farmers to meet their nutritional as well as economic needs, no information is available on habitat, distribution, phenotypic characters and performance of the indigenous goats of Andhra Pradesh and further Andhra Pradesh does not possess any

How to cite this article: Parvathi, L.A., Kumari, P.B., Devi, S.K., Reddy, R.Y. and Vinod, U. (2020). Studies on productive performance and biometry in traditionally reared indigenous goats of Andhra Pradesh. J. Anim. Res., 10(6): 1021-1028.

Source of Support: None; Conflict of Interest: None

(क) 
recognized breed of goats. Therefore, the present study is aimed to assess the performance of indigenous goats under field conditions.

\section{MATERIALS AND METHODS}

\section{Collection of data}

The data on body weights and linear body measurements of 1421 indigenous goats (1081 does and 340 bucks) of various age groups (milk teeth, 2, 4, 6 and 8 teeth age) from 40 villages spread over 20 mandals of four districts (Chittoor, YSR Kadapa, Ananthapur and Kurnool) of Rayalaseema region of Andhra Pradesh were recorded during November 2017 to April 2018. The goat population of the Rayalaseema region is highest in the Andhra Pradesh. Hence, the Rayalaseema region is selected as study area. Data on body weights and biometrical measurements viz., height at wither (HW), chest girth (CG), paunch girth (PG), hip-width (HPW), body length (BL), face length (FL), ear length (EL) and tail length (TL) were collected. Biometrical measurements were recorded using a measuring tape after the animals were made to stand squarely on an even surface. Since, the particulars of the date of birth of animal were not available under field conditions; the eruption of permanent incisor teeth was taken as an indicator of the age of the animal (Turner, 1937). Body weight was measured with the help of a weighing balance with $500 \mathrm{~g}$ accuracy. The body measurements were recorded as per Banait et al. (2002) and Narasimham et al. (2003) as mentioned below:

1. Height at withers: Distance from the base of the hoof to the highest point of withers.

2. Chest girth: Body circumference around the chest, just behind the elbow joint.

3. Body length: Distance from point of shoulder to the point of tuber ischi.

4. Hip width: Distance from the tuberosity prominence to ileum of one side to the other, across the rump.

5. Paunch girth: Body circumference in front of the sacrum.

6. Face length: Distance from midpoint of poll between 2 horns to tip of nose.
7. Ear length: Length of straight line drawn from tip to base of the ear.

8. Tail length: Distance from base to the tip of the tail.

The data on body weights and various biometric measurements were grouped according to the districts and sexes within age groups. The data generated on various traits were subjected to least squares technique (Harvey, 1987) to study the effect of district and sex within each age group by using the following statistical model.

$$
Y_{i j k}=\mu+D_{i}+S_{j+} e_{i j k}
$$

Where,

$Y_{i j k}=$ the measurement on $k^{\text {th }}$ animal belonging to $j^{\text {th }}$ sex and $i^{\text {th }}$ district;

$\mu=$ Overall mean;

$D_{i}=$ Effect of $i^{\text {th }} \operatorname{district}(i=1$ to 4 )

$1=$ Chittoor district

$2=$ YSR Kadapa district

$3=$ Anantapur district

$4=$ Kurnool district

$S_{j}=$ Effect of $j^{\text {th }} \operatorname{sex}(j=1$ for male and 2 for female);

$e_{i j k}=$ random error.

Duncan's multiple range test as modified by Kramer (1957) was employed to make pair wise comparisons of least-squares means.

\section{RESULTS AND DISCUSSION}

\section{Productive Performance}

The overall least squares mean body weights $(\mathrm{kg})$ at milk teeth, 2, 4, 6 and 8-teeth ages were $13.97 \pm 0.16,20.57$ $\pm 0.38,26.56 \pm 0.68,30.66 \pm 0.62$ and $34.64 \pm 0.85$, respectively. Districts had significant $(\mathrm{p}<0.01)$ effect on body weights of 6 and 8 teeth age groups. The mean body weights varied from $28.74 \pm 0.82$ to $33.09 \pm 0.96 \mathrm{~kg}$ at 6-teeth and $33.24 \pm 0.97$ to $36.76 \pm 1.00 \mathrm{~kg}$ at 8 -teeth age in Anantapur and Kurnool, respectively (Table 1). The mean body weights recorded in present study coincided with the previous findings of Ravimurugan et al. (2009) in Pallai Adu goat, but, higher than those reported by Freitas et al. (2004) in Saanen, Fajemilehin and Salako (2008) in West African Dwarf goat, Kumari et al. (2015) in Black Bengal 
Table 1: Least squares mean for body weights $(\mathrm{kg})$ and biometrical measurements $(\mathrm{cm})$ at various ages in indigenous goats

\begin{tabular}{|c|c|c|c|c|c|c|c|c|c|c|}
\hline \multirow[t]{3}{*}{ Factors } & \multicolumn{10}{|c|}{ Age groups } \\
\hline & $\underline{n}$ & Milk Teeth & $\mathbf{n}$ & 2-Teeth & n & 4-Teeth & $\mathbf{n}$ & 6-Teeth & $\mathbf{n}$ & 8-Teeth \\
\hline & \multicolumn{10}{|c|}{ Body Weights (Kgs) } \\
\hline Overall & 533 & $13.97 \pm 0.16$ & 172 & $20.57 \pm 0.38$ & 198 & $26.56 \pm 0.68$ & 218 & $30.66 \pm 0.62$ & 300 & $34.64 \pm 0.85$ \\
\hline \multicolumn{11}{|l|}{ Districts } \\
\hline Chittoor & 162 & $14.17^{\mathrm{a}} \pm 0.28$ & 44 & $20.74^{\mathrm{a}} \pm 0.75$ & 57 & $26.00^{\mathrm{a}} \pm 1.01$ & 61 & $31.31^{\mathrm{b}} \pm 0.91$ & 58 & $34.35^{\mathrm{b}} \pm 1.07$ \\
\hline YSRKadapa & 135 & $14.31^{\mathrm{a}} \pm 0.30$ & 41 & $18.55^{\mathrm{a}} \pm 0.70$ & 43 & $26.18^{\mathrm{a}} \pm 1.11$ & 46 & $29.48^{\mathrm{ab}} \pm 0.99$ & 76 & $34.22^{\mathrm{ab}} \pm 0.97$ \\
\hline Anantapur & 93 & $13.27^{\mathrm{a}} \pm 0.36$ & 50 & $21.09^{\mathrm{a}} \pm 0.68$ & 47 & $26.27^{\mathrm{a}} \pm 1.08$ & 64 & $28.74^{\mathrm{a}} \pm 0.82$ & 79 & $33.24^{\mathrm{a}} \pm 0.99$ \\
\hline Kurnool & 143 & $14.11^{\mathrm{a}} \pm 0.31$ & 37 & $21.89^{\mathrm{a}} \pm 0.73$ & 51 & $27.78^{\mathrm{a}} \pm 1.13$ & 47 & $33.09^{c} \pm 0.96$ & 87 & $36.76^{\mathrm{c}} \pm 1.00$ \\
\hline \multicolumn{11}{|l|}{ Sex } \\
\hline Male & 232 & $14.50^{b} \pm 0.23$ & 50 & $23.06^{\mathrm{b}} \pm 0.66$ & 26 & $32.06^{\mathrm{b}}$ & 22 & $36.29^{\mathrm{b}} \pm 1.19$ & 10 & $40.24^{\mathrm{b}} \pm 1.66$ \\
\hline Female & 301 & $13.43^{\mathrm{a}} \pm 0.21$ & 122 & $18.08^{\mathrm{a}} \pm 0.42$ & 172 & $21.05^{\mathrm{a}}$ & 196 & $25.02^{\mathrm{a}} \pm 0.39$ & 290 & $29.04^{\mathrm{a}} \pm 0.31$ \\
\hline \multicolumn{11}{|c|}{ Height at withers $(\mathrm{cms})$} \\
\hline Overall & 533 & $66.60 \pm 0.29$ & 172 & $74.65 \pm 0.42$ & 198 & $79.50 \pm 0.48$ & 218 & $82.80 \pm 0.55$ & 300 & $84.07 \pm 0.72$ \\
\hline \multicolumn{11}{|l|}{ Districts } \\
\hline Chittoor & 162 & $65.76^{\mathrm{ab}} \pm 0.52$ & 44 & $73.27^{\mathrm{a}} \pm 0.83$ & 57 & $78.24^{\mathrm{a}} \pm 0.72$ & 61 & $82.49^{\mathrm{a}} \pm 0.80$ & 58 & $83.76^{\mathrm{a}} \pm 0.91$ \\
\hline YSRKadapa & 135 & $69.32^{\mathrm{c}} \pm 0.57$ & 41 & $75.47^{\mathrm{ab}} \pm 0.78$ & 43 & $80.91^{\mathrm{a}} \pm 0.79$ & 46 & $84.64^{\mathrm{a}} \pm 0.86$ & 76 & $85.52^{\mathrm{a}} \pm 0.83$ \\
\hline Anantapur & 93 & $66.61^{\mathrm{b}} \pm 0.69$ & 50 & $76.20^{\mathrm{b}} \pm 0.76$ & 47 & $79.09^{\mathrm{a}} \pm 0.77$ & 64 & $81.71^{\mathrm{a}} \pm 0.72$ & 79 & $82.69^{\mathrm{a}} \pm 0.85$ \\
\hline Kurnool & 143 & $64.71^{\mathrm{a}} \pm 0.58$ & 37 & $73.67^{\mathrm{a}} \pm 0.81$ & 51 & $79.76^{\mathrm{a}} \pm 0.80$ & 47 & $82.37^{\mathrm{a}} \pm 0.85$ & 87 & $84.30^{\mathrm{a}} \pm 0.86$ \\
\hline \multicolumn{11}{|l|}{ Sex } \\
\hline$\overline{\text { Male }}$ & 232 & $67.44^{\mathrm{b}} \pm 0.44$ & 50 & $77.06^{\mathrm{b}} \pm 0.73$ & 26 & $83.88^{b} \pm 0.91$ & 22 & $88.35^{\mathrm{b}} \pm 1.04$ & 10 & $88.66^{\mathrm{b}} \pm 1.42$ \\
\hline Female & 301 & $65.77^{a} \pm 0.39$ & 122 & $72.25^{\mathrm{a}} \pm 0.47$ & 172 & $75.11^{\mathrm{a}} \pm 0.35$ & 196 & $77.26^{\mathrm{a}} \pm 0.35$ & 290 & $79.47^{\mathrm{a}} \pm 0.27$ \\
\hline \multicolumn{11}{|c|}{ Chest girth (cms) } \\
\hline Overall & 533 & $60.08 \pm 0.25$ & 172 & $69.55 \pm 0.39$ & 198 & $76.07 \pm 0.43$ & 218 & $79.96 \pm 0.51$ & 300 & $82.83 \pm 0.69$ \\
\hline \multicolumn{11}{|l|}{ Districts } \\
\hline Chittoor & 162 & $59.69^{\mathrm{a}} \pm 0.43$ & 44 & $67.95^{\mathrm{a}} \pm 0.76$ & 57 & $74.36^{\mathrm{a}} \pm 0.64$ & 61 & $79.18^{a} \pm 0.75$ & 58 & $82.39^{\mathrm{a}} \pm 0.87$ \\
\hline YSRKadapa & 135 & $62.39^{b} \pm 0.47$ & 41 & $68.74^{\mathrm{ab}} \pm 0.71$ & 43 & $77.07^{\mathrm{c}} \pm 0.70$ & 46 & $79.98^{a} \pm 0.81$ & 76 & $83.49^{\mathrm{a}} \pm 0.78$ \\
\hline Anantapur & 93 & $62.42^{\mathrm{b}} \pm 0.57$ & 50 & $72.11^{\mathrm{c}} \pm 0.69$ & 47 & $76.85^{\mathrm{bc}} \pm 0.68$ & 64 & $80.22^{\mathrm{a}} \pm 0.67$ & 79 & $82.23^{\mathrm{a}} \pm 0.81$ \\
\hline Kurnool & 143 & $59.83^{\mathrm{a}} \pm 0.49$ & 37 & $69.39^{b} \pm 0.74$ & 51 & $76.01^{b} \pm 0.71$ & 47 & $80.45^{\mathrm{a}} \pm 0.79$ & 87 & $83.19^{\mathrm{a}} \pm 0.81$ \\
\hline \multicolumn{11}{|l|}{ Sex } \\
\hline Male & 232 & $61.75^{\mathrm{b}} \pm 0.37$ & 50 & $71.73^{b} \pm 0.67$ & 26 & $81.07^{b} \pm 0.80$ & 22 & $85.03^{\mathrm{b}} \pm 0.97$ & 10 & $87.19^{b} \pm 1.35$ \\
\hline Female & 301 & $60.41^{\mathrm{a}} \pm 0.32$ & 122 & $67.36^{\mathrm{a}} \pm 0.43$ & 172 & $71.07^{\mathrm{a}} \pm 0.31$ & 196 & $74.88^{a} \pm 0.32$ & 290 & $78.46^{\mathrm{a}} \pm 0.25$ \\
\hline \multicolumn{11}{|c|}{ Body length (cms) } \\
\hline Overall & 533 & $53.24 \pm 0.25$ & 172 & $59.07 \pm 0.50$ & 198 & $63.84 \pm 0.57$ & 218 & $67.13 \pm 0.57$ & 300 & $69.66 \pm 0.99$ \\
\hline \multicolumn{11}{|l|}{ Districts } \\
\hline Chittoor & 162 & $52.42^{\mathrm{ab}} \pm 0.44$ & 44 & $58.92^{\mathrm{a}} \pm 0.98$ & 57 & $62.79^{\mathrm{a}} \pm 0.85$ & 61 & $67.82^{\mathrm{a}} \pm 0.84$ & 58 & $69.32^{\mathrm{a}} \pm 1.25$ \\
\hline YSRKadapa & 135 & $54.61^{\mathrm{c}} \pm 0.48$ & 41 & $58.30^{\mathrm{a}} \pm 0.92$ & 43 & $64.23^{\mathrm{a}} \pm 0.94$ & 46 & $67.00^{\mathrm{a}} \pm 0.91$ & 76 & $69.72^{\mathrm{a}} \pm 1.13$ \\
\hline Anantapur & 93 & $53.81^{\mathrm{bc}} \pm 0.58$ & 50 & $59.82^{\mathrm{a}} \pm 0.89$ & 47 & $63.42^{\mathrm{a}} \pm 0.91$ & 64 & $65.91^{\mathrm{a}} \pm 0.75$ & 79 & $68.62^{\mathrm{a}} \pm 1.17$ \\
\hline$\underline{\text { Kurnool }}$ & 143 & $52.11^{\mathrm{a}} \pm 0.49$ & 37 & $59.24^{\mathrm{a}} \pm 0.96$ & 51 & $64.92^{\mathrm{a}} \pm 0.95$ & 47 & $67.80^{\mathrm{a}} \pm 0.89$ & 87 & $70.97^{\mathrm{a}} \pm 1.18$ \\
\hline \multicolumn{11}{|l|}{ Sex } \\
\hline$\overline{\text { Male }}$ & 232 & $53.19^{\mathrm{a}} \pm 0.37$ & 50 & $60.40^{\mathrm{b}} \pm 0.86$ & 26 & $67.03^{b} \pm 1.07$ & 22 & $70.95^{\mathrm{b}} \pm 1.09$ & 10 & $73.72^{\mathrm{b}} \pm 1.95$ \\
\hline Female & 301 & $53.28^{\mathrm{a}} \pm 0.33$ & 122 & $57.74^{\mathrm{a}} \pm 0.55$ & 172 & $60.64^{\mathrm{a}} \pm 0.41$ & 196 & $63.32^{\mathrm{a}} \pm 0.36$ & 290 & $65.59^{\mathrm{a}} \pm 0.36$ \\
\hline \multicolumn{11}{|c|}{ Hip width (cm) } \\
\hline Overall & 533 & $13.02 \pm 0.08$ & 172 & $15.04 \pm 0.14$ & 198 & $16.71 \pm 0.38$ & 218 & $17.55 \pm 0.21$ & 300 & $18.05 \pm 0.56$ \\
\hline \multicolumn{11}{|l|}{ Districts } \\
\hline Chittoor & 162 & $12.73^{\mathrm{a}} \pm 0.15$ & 44 & $14.74^{\mathrm{a}} \pm 0.27$ & 57 & $16.00^{\mathrm{a}} \pm 0.57$ & 61 & $17.63^{\mathrm{b}} \pm 0.31$ & 58 & $17.68^{\mathrm{ab}} \pm 0.71$ \\
\hline YSRKadapa & 135 & $13.62^{\mathrm{c}} \pm 0.16$ & 41 & $15.19^{\mathrm{a}} \pm 0.26$ & 43 & $16.64^{\mathrm{a}} \pm 0.63$ & 46 & $17.95^{\mathrm{bc}} \pm 0.34$ & 76 & $18.16^{\mathrm{b}} \pm 0.64$ \\
\hline Anantapur & 93 & $12.58^{\mathrm{a}} \pm 0.20$ & 50 & $14.80^{\mathrm{a}} \pm 0.25$ & 47 & $17.01^{\mathrm{a}} \pm 0.61$ & 64 & $16.44^{\mathrm{a}} \pm 0.28$ & 79 & $16.78^{a} \pm 0.66$ \\
\hline Kurnool & 143 & $13.14^{\mathrm{b}} \pm 0.17$ & 37 & $15.43^{\mathrm{a}} \pm 0.27$ & 51 & $17.20^{\mathrm{a}} \pm 0.64$ & 47 & $18.18^{c} \pm 0.33$ & 87 & $19.57^{\mathrm{c}} \pm 0.67$ \\
\hline
\end{tabular}




\begin{tabular}{|c|c|c|c|c|c|c|c|c|c|c|}
\hline Sex & & & & & & & & & & \\
\hline Male & 232 & $13.00^{\mathrm{a}} \pm 0.12$ & 50 & $15.19^{a} \pm 0.24$ & 26 & $17.47^{\mathrm{a}} \pm 0.72$ & 22 & $18.54^{\mathrm{b}} \pm 0.41$ & 10 & $18.34^{\mathrm{a}} \pm 1.10$ \\
\hline Female & 301 & $13.04^{\mathrm{a}} \pm 0.11$ & 122 & $14.89^{\mathrm{a}} \pm 0.15$ & 172 & $15.96^{\mathrm{a}} \pm 0.27$ & 196 & $16.57^{\mathrm{a}} \pm 0.13$ & 290 & $17.76^{\mathrm{a}} \pm 0.21$ \\
\hline \multicolumn{11}{|c|}{ Paunch girth (cms) } \\
\hline Overall & 533 & $61.05 \pm 0.27$ & 172 & $69.11 \pm 0.45$ & 198 & $74.37 \pm 0.74$ & 218 & $79.02 \pm 0.68$ & 300 & $83.50 \pm 0.95$ \\
\hline \multicolumn{11}{|l|}{ Districts } \\
\hline Chittoor & 162 & $60.10^{\mathrm{a}} \pm 0.48$ & 44 & $67.02^{\mathrm{a}} \pm 0.87$ & 57 & $74.11^{\mathrm{a}} \pm 1.11$ & 61 & $77.63^{\mathrm{a}} \pm 1.00$ & 58 & $83.40^{\mathrm{a}} \pm 1.20$ \\
\hline YSRKadapa & 135 & $62.39^{\mathrm{b}} \pm 0.53$ & 41 & $69.02^{\mathrm{ab}} \pm 0.82$ & 43 & $73.18^{\mathrm{a}} \pm 1.22$ & 46 & $77.93^{\mathrm{a}} \pm 1.08$ & 76 & $84.22^{\mathrm{a}} \pm 1.09$ \\
\hline Anantapur & 93 & $61.97^{\mathrm{b}} \pm 0.63$ & 50 & $71.35^{\mathrm{b}} \pm 0.80$ & 47 & $75.76^{\mathrm{a}} \pm 1.19$ & 64 & $80.63^{b} \pm 0.89$ & 79 & $83.05^{\mathrm{a}} \pm 1.12$ \\
\hline Kurnool & 143 & $59.75^{\mathrm{a}} \pm 0.54$ & 37 & $69.06^{\mathrm{b}} \pm 0.86$ & 51 & $74.41^{\mathrm{a}} \pm 1.24$ & 47 & $79.91^{\mathrm{b}} \pm 1.06$ & 87 & $83.31^{\mathrm{a}} \pm 1.13$ \\
\hline \multicolumn{11}{|l|}{ Sex } \\
\hline Male & 232 & $61.89^{\mathrm{b}} \pm 0.40$ & 50 & $70.09^{b} \pm 0.77$ & 26 & $77.59^{\mathrm{b}} \pm 1.39$ & 22 & $82.25^{\mathrm{b}} \pm 1.30$ & 10 & $87.36^{\mathrm{b}} \pm 1.87$ \\
\hline Female & 301 & $60.21^{\mathrm{a}} \pm 0.36$ & 122 & $68.13^{a} \pm 0.49$ & 172 & $71.14^{\mathrm{a}} \pm 0.53$ & 196 & $75.80^{a} \pm 0.43$ & 290 & $79.63^{a} \pm 0.35$ \\
\hline \multicolumn{11}{|c|}{ Face length $(\mathrm{cms})$} \\
\hline Overall & 533 & $16.65 \pm 0.10$ & 172 & $18.42 \pm 0.12$ & 198 & $19.88 \pm 0.20$ & 218 & $20.28 \pm 0.22$ & 300 & $20.78 \pm 0.24$ \\
\hline \multicolumn{11}{|l|}{ Districts } \\
\hline Chittoor & 162 & $16.67^{a} \pm 0.18$ & 44 & $18.14^{\mathrm{a}} \pm 0.24$ & 57 & $19.63^{\mathrm{a}} \pm 0.30$ & 61 & $20.24^{\mathrm{a}} \pm 0.33$ & 58 & $20.53^{\mathrm{ab}} \pm 0.30$ \\
\hline YSRKadapa & 135 & $16.53^{a} \pm 0.20$ & 41 & $17.95^{\mathrm{a}} \pm 0.23$ & 43 & $20.06^{\mathrm{a}} \pm 0.33$ & 46 & $20.10^{\mathrm{a}} \pm 0.35$ & 76 & $20.89^{b} \pm 0.27$ \\
\hline Anantapur & 93 & $16.57^{\mathrm{a}} \pm 0.24$ & 50 & $18.84^{b} \pm 0.22$ & 47 & $19.72^{\mathrm{a}} \pm 0.32$ & 64 & $20.09^{\mathrm{a}} \pm 0.29$ & 79 & $20.45^{\mathrm{a}} \pm 0.28$ \\
\hline Kurnool & 143 & $16.86^{\mathrm{a}} \pm 0.20$ & 37 & $18.78^{b} \pm 0.24$ & 51 & $20.12^{\mathrm{a}} \pm 0.33$ & 47 & $20.69^{\mathrm{a}} \pm 0.35$ & 87 & $21.26^{\mathrm{c}} \pm 0.28$ \\
\hline \multicolumn{11}{|l|}{ Sex } \\
\hline Male & 232 & $16.78^{a} \pm 0.15$ & 50 & $19.25^{\mathrm{b}} \pm 0.21$ & 26 & $21.22^{b} \pm 0.38$ & 22 & $21.45^{\mathrm{b}} \pm 0.43$ & 10 & $21.61^{b} \pm 0.46$ \\
\hline Female & 301 & $16.52^{\mathrm{a}} \pm 0.13$ & 122 & $17.60^{\mathrm{a}} \pm 0.14$ & 172 & $18.55^{\mathrm{a}} \pm 0.14$ & 196 & $19.11^{\mathrm{a}} \pm 0.14$ & 290 & $19.96^{\mathrm{a}} \pm 0.09$ \\
\hline \multicolumn{11}{|c|}{ Ear length (cms) } \\
\hline Overall & 533 & $14.66 \pm 0.08$ & 172 & $15.31 \pm 0.14$ & 198 & $15.90 \pm 0.17$ & 218 & $16.06 \pm 0.18$ & 300 & $16.39 \pm 0.30$ \\
\hline \multicolumn{11}{|l|}{ Districts } \\
\hline Chittoor & 162 & $14.18^{a} \pm 0.14$ & 44 & $14.41^{\mathrm{a}} \pm 0.28$ & 57 & $15.61^{a} \pm 0.26$ & 61 & $15.77^{a} \pm 0.26$ & 58 & $16.51^{a} \pm 0.37$ \\
\hline YSRKadapa & 135 & $14.88^{b} \pm 0.15$ & 41 & $15.41^{\mathrm{b}} \pm 0.27$ & 43 & $15.71^{\mathrm{a}} \pm 0.28$ & 46 & $16.08^{\mathrm{a}} \pm 0.29$ & 76 & $16.50^{\mathrm{a}} \pm 0.34$ \\
\hline Anantapur & 93 & $15.25^{\mathrm{b}} \pm 0.18$ & 50 & $15.76^{\mathrm{b}} \pm 0.26$ & 47 & $16.16^{\mathrm{a}} \pm 0.28$ & 64 & $16.43^{\mathrm{a}} \pm 0.24$ & 79 & $16.31^{\mathrm{a}} \pm 0.35$ \\
\hline Kurnool & 143 & $14.35^{\mathrm{a}} \pm 0.15$ & 37 & $15.68^{b} \pm 0.28$ & 51 & $16.10^{\mathrm{a}} \pm 0.29$ & 47 & $15.95^{\mathrm{a}} \pm 0.28$ & 87 & $16.25^{\mathrm{a}} \pm 0.35$ \\
\hline \multicolumn{11}{|l|}{ Sex } \\
\hline Male & 232 & $14.73^{a} \pm 0.11$ & 50 & $15.53^{a} \pm 0.25$ & 26 & $16.44^{b} \pm 0.32$ & 22 & $16.55^{\mathrm{b}} \pm 0.34$ & 10 & $17.01^{b} \pm 0.58$ \\
\hline Female & 301 & $14.59^{\mathrm{a}} \pm 0.10$ & 122 & $15.09^{\mathrm{a}} \pm 0.16$ & 172 & $15.35^{\mathrm{a}} \pm 0.12$ & 196 & $15.56^{\mathrm{a}} \pm 0.11$ & 290 & $15.78^{a} \pm 0.11$ \\
\hline \multicolumn{11}{|c|}{ Tail length (cms) } \\
\hline Overall & 533 & $14.51 \pm 0.09$ & 172 & $15.11 \pm 0.16$ & 198 & $15.42 \pm 0.20$ & 218 & $15.84 \pm 2.59$ & 300 & $16.56 \pm 0.32$ \\
\hline \multicolumn{11}{|l|}{ Districts } \\
\hline Chittoor & 162 & $13.87^{a} \pm 0.16$ & 44 & $14.74^{\mathrm{a}} \pm 0.31$ & 57 & $15.59^{a} \pm 0.31$ & 61 & $15.81^{\mathrm{a}} \pm 3.78$ & 58 & $17.23^{c} \pm 0.40$ \\
\hline YSRKadapa & 135 & $14.56^{\mathrm{b}} \pm 0.17$ & 41 & $15.05^{\mathrm{a}} \pm 0.29$ & 43 & $15.24^{\mathrm{a}} \pm 0.34$ & 46 & $15.47^{\mathrm{a}} \pm 4.09$ & 76 & $16.65^{\mathrm{bc}} \pm 0.36$ \\
\hline Anantapur & 93 & $15.20^{c} \pm 0.21$ & 50 & $15.06^{\mathrm{a}} \pm 0.28$ & 47 & $15.02^{\mathrm{a}} \pm 0.33$ & 64 & $15.77^{\mathrm{a}} \pm 3.39$ & 79 & $16.08^{a} \pm 0.37$ \\
\hline Kurnool & 143 & $14.40^{\mathrm{b}} \pm 0.18$ & 37 & $15.59^{\mathrm{a}} \pm 0.30$ & 51 & $15.84^{\mathrm{a}} \pm 0.34$ & 47 & $16.31^{\mathrm{a}} \pm 4.00$ & 87 & $16.27^{\mathrm{ab}} \pm 0.38$ \\
\hline \multicolumn{11}{|l|}{ Sex } \\
\hline Male & 232 & $14.84^{b} \pm 0.13$ & 50 & $15.75^{b} \pm 0.27$ & 26 & $16.41^{b} \pm 0.38$ & 22 & $17.05^{\mathrm{a}} \pm 4.92$ & 10 & $17.88^{b} \pm 0.62$ \\
\hline Female & 301 & $14.17^{\mathrm{a}} \pm 0.12$ & 122 & $14.48^{a} \pm 0.17$ & 172 & $14.44^{\mathrm{a}} \pm 0.15$ & 196 & $14.63^{\mathrm{a}} \pm 1.64$ & 290 & $15.24^{\mathrm{a}} \pm 0.12$ \\
\hline
\end{tabular}

Means followed by same superscript(s) do not differ significantly $(\mathrm{p}<0.05)$; $\mathrm{n}=$ number of animals 
and Jharkhand black, Selolo et al. (2015) in goats of South Africa, while, Freitas et al. (2004) in Anglonubian, Pesmen and Yardimci (2008) in Saanen, Thiruvenkadan and Panneerselvam (2009) in Kanni Adu, Chitra et al. (2012) in Malabari, Gopu et al. (2013) in Salem Black, Hilal et al. (2013) in Beni Arrous local goats, Kuralkar et al. (2013) in Berari, Siddalingamurthy et al. (2017) in Karnataka local goats and Vinod and PunyaKumari (2019) in local goats of Andhra Pradesh reported higher body weights than those observed in the present study. The variation of body weights at different ages among males and females might be due to the dominant and aggressive behavior of males, anabolic effect of hormones presents in males and variation in genetic constitution of the animals (Hafez, 1962).

\section{Biometrical measurements}

All the biometrical parameters revealed increasing trend with the advancement of the age. Sexual dimorphism was observed for all the biometrical traits, where males recorded significantly $(\mathrm{p}<0.01)$ higher means than females. Considerable variation between districts was also observed for all the parameters under study (Table 1).

\section{Height at withers}

The overall least squares mean for height at withers at milk teeth, 2, 4, 6 and 8 teeth of age were $66.60 \pm 0.29$, $74.65 \pm 0.42,79.50 \pm 0.48,82.80 \pm 0.55$ and $84.07 \pm 0.72$ $\mathrm{cm}$, respectively (Table 1). The height at withers increased with age and significant $(\mathrm{p}<0.01)$ differences were recorded among geographical (districts) locations. The means recorded in the current findings were higher than those reported by Jimmy et al. (2010) in goats of Uganda, Chacon et al. (2011) in Cuban Creole goats, Manzi et al. (2011) in goats of Rwanda, Chitra et al. (2012) in Malabari goat. Males were taller by 1.67, 4.81, 8.77, 11.09 and $9.19 \mathrm{~cm}$ than females at milk teeth to 8- teeth of age, respectively. Thiruvenkadan and Panneerselvam (2009) in Kanni Adu goat recorded higher means for height at withers in males at 8 - teeth than those observed in the present study. The indigenous goats of Andhra Pradesh recorded higher means for height at withers which might be due to variation in the germplasm/genetic base of the populations, growth rate and the habitat under which the animals are maintained.

\section{Chest girth}

The overall least squares mean for chest girth at milk teeth, 2, 4, 6 and 8 teeth age groups were $61.08 \pm 0.25$, $69.55 \pm 0.39,76.07 \pm 0.43,79.96 \pm 0.51$ and $82.83 \pm$ $0.69 \mathrm{~cm}$, respectively. Chest girth is one of the important contributors for prediction of body weight which indicates the lung capacity and rib cage circumference. The mean chest girth recorded in the present study coincided with the findings of Verma et al. (2015) in Singharey and Vinod and PunyaKumari (2019) in local goats of Andhra Pradesh, but higher to those reported by Jimmy et al. (2010) in goats of Uganda, Manzi et al. (2011) in goats of Rwanda, Chitra et al. (2012) in Malabari goat, Gopu et al. (2013) in Salem black males. The present findings revealed significant $(\mathrm{p}<0.01)$ variations among flocks maintained in four districts of Andhra Pradesh at milk teeth, 2- and 4- teeth of ages, which could be attributed to the variation in environmental factors, plane of nutrition, breeding and managemental practices being adopted by the farmers of different districts. Highly significant $(p<0.01)$ variations between males and females was observed for chest girth at all age groups studied. Males had higher chest girth than the females at all ages studied, which could be due to the effect of differential expression of sex harmones on the chest girth and higher body weights in males.

\section{Body length}

The overall least squares mean for body length at milk teeth, 2, 4, 6 and 8 teeth of age were $53.24 \pm 0.25,59.07$ $\pm 0.50,63.84 \pm 0.57,67.13 \pm 0.57$ and $69.66 \pm 0.99 \mathrm{~cm}$, respectively and were lower compared to earlier findings of Dixit et al. (2013) in Surti, Gopu et al. (2013) in Salem black, Verma et al. (2015) in Singharey, Mandakmale et al. (2016) in Kathewadi, Vinod and PunyaKumari (2019) in local goats of Andhra Pradesh, while, the values reported in the present study were higher compared to findings in Pantja goat by Ravimuragan et al. (2009). The body length among the goat populations of Chittoor, YSR Kadapa, Anantapur and Kurnool districts showed non-significant $(p \leq 0.05)$ differences at all age groups except at milk teeth age. Body length of males were significantly $(p<0.01)$ higher than females by the difference of $2.66,6.39,7.63$ and $8.13 \mathrm{~cm}$ at 2-, 4-, 6- and 8- teeth age, respectively, which could be attributed to sexual dimorphism. 


\section{Hip width}

The overall least squares means for hip width at milk teeth, 2, 4, 6 and 8 teeth of age were $13.02 \pm 0.08,15.04$ $\pm 0.14,16.71 \pm 0.38,17.55 \pm 0.21$ and $18.05 \pm 0.56$ $\mathrm{cm}$, respectively and were higher than the mean values recorded in West African Dwarf Goat of South western Nigeria (Fajemilehin and Salako, 2008), goat breeds of Uganda (Jimmy et al., 2010) and local goats of Andhra Pradesh (Vinod and Punya Kumari 2019). The hip width of the goats was significantly influenced $(p<0.01)$ by districts at milk teeth, 6 and 8- teeth ages studied. Sex had no significant effect at all ages except at 6 teeth of age, where males shown higher hip width than females by 1.97 $\mathrm{cm}$. highest hip widths (19.57) was noticed in Kurnool district at 8 teeth age group. Varied climatic conditions, plane of nutrition and managemental practices being followed by the farmers might have resulted in variation of body weights, growth rate and hip width among different districts studied.

\section{Paunch girth}

The least squares mean for paunch girth at milk teeth, 2, 4, 6 and 8 teeth of age were $61.05 \pm 0.27,69.11 \pm$ $0.45,74.37 \pm 0.74,79.02 \pm 0.68$ and $83.50 \pm 0.95 \mathrm{~cm}$, respectively. The means calculated in the present study were lower compared to the values observed in Singharey goat of Sikkim (Verma et al., 2015), Karnataka goats (Siddalingamurthy et al., 2017).

In contrast to the present findings, lower means for paunch girth were recorded in Bakerwali female goats at 8- teeth (Reotheia et al., 2013) and higher values were recorded in Bakerwali male goats by Reotheia et al. (2013). The sex effect on paunch girth was highly significant $(p \leq 0.01$ and indeed males had higher paunch girth than females at all ages studied. The increase of paunch girth from milk teeth to 8- teeth was $25.47 \mathrm{~cm}$ in males and $19.42 \mathrm{~cm}$ in females in present study revealed that the skeletal frame and muscular growth of the bucks and does is different and increased with the age.

\section{Face length}

The overall least-squares means of face length at milk teeth, 2, 4, 6 and 8-teeth age were $16.65 \pm 0.10,18.42$ $\pm 0.12,19.88 \pm 0.20,20.28 \pm 0.22$ and $20.78 \pm 0.24 \mathrm{~cm}$, respectively. The mean face length recorded in the present study was higher than those reported in Surti (Dixit et al., 2013), Singharey (Verma et al., 2015) and local goats of AP (Vinod and Punya Kumari 2019), while, Gopu et al. (2013) in Salem black males and females at 8- teeth and 6teeth of age recorded higher means than the present study and Reotheia et al. (2013) in female Bakerwali at all ages. Males had slightly higher face length values than females at all ages except at milk teeth age which corroborated with the findings of Reddy (2004) in Mahabubnagar goats.

\section{Ear length}

The overall least squares mean for ear length at milk teeth 2, 4, 6 and 8-teeth age were $14.66 \pm 0.08,15.31 \pm$ $0.14,15.90 \pm 0.17,16.06 \pm 0.18$ and $16.39 \pm 0.30 \mathrm{~cm}$, respectively. There was not much growth in length of ear from 4-teeth age to 8-teeth age in indigenous goats of Andhra Pradesh. Males recorded higher mean values for ear length than females at 4, 6 and 8- teeth ages. The means in the present study were nearly close to the observations reported in Mahabubnagar goats Berari goats (Kuralkar et al., 2013), but, lower compared to earlier findings Hassen et al. (2016) in Syrian goat breeds (Baladi, Jabali, Shami) and AP local goats (Vinod and Punya Kumari 2019).

\section{Tail length}

The overall least-squares mean of tail length at milk teeth, 2, 4, 6 and 8-teeth age were $14.51 \pm 0.09,15.11$ $\pm 0.16,15.42 \pm 0.20,15.84 \pm 2.59$ and $16.56 \pm 0.32 \mathrm{~cm}$, respectively (Table 1) and these values were coincided with earlier findings of Ravimurugan et al. (2009) in Pallai Adu, but, higher than those reported by Kuralkar et al. (2013) in Berari, Verma et al. (2015) in Singharey goats of Sikkim and Vinod and PunyaKumari (2019) in local goats of Andhra Pradesh. The effect of district was significant on tail length at milk teeth and 8- teeth of age studied. Sex had significant effect $(p<0.01)$ on tail length and males expressed higher mean values over females at all ages studied except at 6 - teeth which can be correlated with higher growth and other biometrical measurements and sex hormones.

\section{CONCLUSION}

The overall least squares mean body weights $(\mathrm{kg})$ at milk teeth, 2, 4, 6 and 8-teeth ages were $13.97 \pm 0.16,20.57$ 
$\pm 0.38,26.56 \pm 0.68,30.66 \pm 0.62$ and $34.64 \pm 0.85$, respectively. The least squares analysis of variance revealed significant effects of district and sex on body weights and measurements at one or the other ages studied. The body weights and biometrical measurements linearly increased with age. Sexual dimorphism was evident, where males recorded significantly higher means than females at all the stages of growth. The animals in YSR Kadapa district showed higher mean values for body weights all the ages studied.

\section{REFERENCES}

Banait, H.B., Ali, S.Z. and Kuralkar, S.V. 2002. Variation in body conformation traits in different breeds of goats. Ind. Vet. J., 79: 591-594.

Chacón, E., Macedo, F., Velázquez, F., Paiva, S.R., Pineda, E. and McManus, C. 2011. Morphological measurements and body indices for Cuban Creole goats and their crossbreds. Rev. B. de Zootech., 40(8): 1671-1679.

Chitra, R., Rajendran, S., Prasanna, D. and Kirubakaran, A. 2012. Prediction of body weight using appropriate regression model in adult female Malabari goat. Vet. World., 5(7): 409411.

Dixit, S.P., Aggarwal, R.A.K., Dangi, P.S., Verma, N.K., Vyas, M.K., Rana, J., Sharma, A., Kharadi, V.B., Sabapara, G.P. and Deshpande, S.B. 2013. Phenotypic characteristics, management, performance and genetic variability in Surti breed of goat. Ind. J. Ani. Sci., 83(4): 423-427.

Fajemilehin, O.K.S. and Salako, A.E. 2008. Body measurement characteristics of the West African Dwarf (WAD) goat in deciduous forest zone of Southwestern Nigeria. Afr. $J$. Biotech., 7(14): 2521-2526.

Freitas, V.J.F., Lopes-Junior, E.S., Rondina, D., SalmitoVanderley, C.S.B., Salles, H.O., Simplício, A.A. Baril, G. and Saumande, J. 2004. Puberty in Anglo-Nubian and Saanen female kids raised in the semi-arid of North-Eastern Brazil. $S$. Rum. Res., 53(1): 167-172.

Gopu, P., Raman, K.S., Thangaraju, P., Saravanan, R. and Panneerselvam, S. 2013. Breed characteristics of Salem black goat of Tamil Nadu. Sha. Int. J. Vet. Sci., 1(1): 15-19.

Hafez, E.S.E. 1962. Reproduction in farm animals. Lea and Febiger, Philadelphia.

Harvey, W.R. 1987. Least-square analysis of data with unequal subclass numbers. ARS H-4, USDA, Washington, DC.

Hassen, H., Rischkowsky, B., Termanini, A., Jessry, G., Haile, A., Baum, M. and Lababidi, S. 2016. Morphological and molecular genetic diversity of Syrian indigenous goat populations. Afr J. Biotech., 15(18): 745-758.
Hilal, B., El Otmani, S., Chentouf, M. and Boujenane, I. (2013). Morphological characterization of the local goat population "Beni Arouss". In Proceedings of 8th International Seminar of the Sub-Network on Production Systems of the FAOCICHEAM., 108: 433-437.

Jimmy, S., David, M., Donald, K.R. and Dennis, M. 2010. Variability in body morphometric measurements and their application in predicting live body weight of Mubende and Small East African goat breeds in Uganda. Middle-E. J. Sci. Res., 5(2): 98-105.

Kramer, C.Y. 1957. Extension of multiple range test to group correlated adjusted means. Biometrics., 13: 13.

Kuralkar, S.V., Verma, N.K., Kharkar, K. and Kuralkar, P. 2013. Berari goats: characterization, management, performance and population status. Ind. J. Ani. Sci., 83(12): 1292-1298.

Livestock Census. 2019. http://dahd.nic.in.

Mandakmale, S.D., Mane, S.H. and Kankhare, D.H. 2016. Morphological characterization of Kathewadi goat breed (Unexplored) of Khandesh region Maharashtra. Int. Res. J. Multi. Stud., 2(2): 1-7.

Manzi, M., Rutagwenda, T., Kanuya, N. and Chatikobo, P. 2011. Phenotypic characterization of goats raised under traditional husbandry systems in Bugesera and Nyagatare districts of Rwanda. J. Ani. \& Vet. Adv., 10(24): 3297-3302.

Narsimham, S.A.L., Narasimha Rao, G., Ramesh Gupta, B., Eswara Reddy, C. and Satyanarayana, A. 2003. A Study on body weights and biometrical measurements of Nellore sheep reared under farm conditions. Cheiron., 32: 55-59.

Pesmen, G. and Yardimci, M. 2008. Estimating the live weight using some body measurements in Saanen goats. Arc. Zootech., 11(4): 30-40.

Ravimurugan, T., Devendran, P., Cauveri, D. and Balachandran, S. 2009. Performance of indigenous goat (Pallai adu) under field conditions. Tam. J. Vet. \& Ani. Sci., 5(5): 203-207.

Reddy, K.V.K. 2004. Studies on phenotypic characterization of Mahabubnagar goats of Andhra Pradesh. M.V.Sc. Thesis submitted to Sri Venkateswara Veterinary University, Tirupathi.

Reotheia, A., Khan, A. and Suri, S. 2013. Morpho-Metric traits of the Bakerwali goat under migratory production system. Ind. Vet. J., 90(12): 22-25.

Siddalingamurthy, H.K., Manjunatha, S.S. and Sreesujatha, R.M. 2017. Determination of regression model for prediction of body weight in local goats of Mandya district in Karnataka. Int. J. I. Res. \& Adv. S (IJIRAS)., 4(3): 182-184.

Thiruvenkadan, A.K. and Panneerselvam, S. 2009. Body weight and its association with body measurements in Kanni Adu goats. Ind. Vet. J., 86(5): 487-490. 
Turner, C.W. 1937. Dairy goat in Missouri. Agricultural experiment station. University of Missouri. Bulletin., 375: 9.

Verma, N.K., Aggarwal, R.A.K., Sharma, R., Dangi, P.S. and Bhutia, N.T. 2015. Phenotypic characterization, biometry and management of Singharey goat of Sikkim. Ind. J. Ani. Sci.., 85(7): 134-136.
Vinod and Punya Kumari. 2019. A study on body weights and biometrical measurements of indigenous goats under field conditions. Int. J. Liv. Res., 9(5). 